\title{
CORPORATIVISMO ESTATAL E SOCIETAL: ESTATUTO DO MINISTÉRIO PÚBLICO E PROPOSTA DE DEFENSORIA-GERAL DA JUSTIÇA*
}

\author{
Alfredo Attié Junior ${ }^{1}$ \\ Juiz de Direito em São Paulo \\ Doutorando em Filosofia Política pela FFLCH USP
}

"Yea but I vilifie the present times, you say, whiles I expect a more flourishing state to succeed; be it so, yet this is not to vilifie modernitie, as you pretend".

Resumo:

O artigo procura recuperar as idéias da representação e da legitimidade ligadas ao tema do sufrágio universal e bem delimitar os contornos do conceito de legitimação para o fim de criticar o estatuto constitucional e legal do Ministério Público no Brasil e propor a conformação de um órgão mais compatível com a idéia de um corporativismo societal em contraposição àquele estatal , a Defensoria-Geral da Justiça. Discorre sobre as conseqüências do Princípio Democrático constitucionalmente conformado sobre a configuração dos instrumentos de garantia dos direitos fundamentais, propondo uma organização do poder judiciário ou judicial mais compatível com tais princípios e a institucionalização da ação civil pública e da ação direta de inconstitucionalidade (com as características de uma verdadeira ação) como instrumentos basilares, restaurados o princípio democrático, e a representação e a legitimidade atentas ao imperativo constitucional do sufrágio. Preocupa-se com a idéia de formação dos profissionais jurídicos, em face do conceito de civilização e da participação e controle da sociedade sobre tal formação. Propõe a ampliação da legitimidade para a propositura de ação direta de inconstitucionalidade e a reconfiguração da legitimidade para a propositura da ação civil pública, restaurando a natureza e o regime jurídicos dos interesses sociais, coletivos e difusos, distinguindo-os do interesse público enquanto interesse estatal.

* No XIII Congresso Brasileiro de Magistrados, Vitória, Espírito Santo, Brasil, 1993.

1. Foi advogado e Procurador do Estado de São Paulo, tendo sido docente do Departamento de Filosofia e Teoria Geral do Direito da Faculdade de Direito da Universidade de São Paulo e do Departamento de Direito da Universidade Estadual Paulista (UNESP). 


\begin{abstract}
:
This paper intends to discuss the concepts of representation and legitimacy by reference to the Democratic Principle. It criticizes the brazilian Public Attorney Statute and proposes the idea of an institution, called "Defensoria-Geral da Justiça" on develloping the idea of a societal consciousness. By giving suggestions to increase the legal definition of the judicial power, it demonstrates the necessity to the society to be aware of the education of the legal professionals. Otherwise it demonstrates the need to modificate the statute of some constitutional remedies and guarantees.
\end{abstract}

Unitermos: Ministério Público, Defensoria-Geral da Justiça, Corporativismo Societal.

1. A atual Constituição Federal brasileira é bastante explícita ao estipular o princípio democrático e a forma de sua expressão concreta: "todo o poder emana do povo, que o exerce por meio de representantes eleitos, ou diretamente, nos termos desta Constituição" (parágrafo único do artigo primeiro).

A origem do poder encontra-se no povo.

Seu exercício, contudo, pode ser direto - que a Constituição parece entender como excepcional - ou por meio de representantes.

Quando se estabelece a representação - a Constituição é clara sua legitimidade se afere pela eleição.

Em conclusão, nossa Charta Magna apenas admite a interposição do representante se legitimado pela eleição.

Tal forma de democracia representativa, qualificada pela necessidade do sufrágio, gera consequiências de extrema relevância, às quais, talvez, a doutrina não tenha voltado suficiente atenção. ${ }^{2}$

2. Os comentários, a rigor, são lacônicos, no que diz respeito a retirar do princípio tais conseqüências. Para citar dois exemplos: 'a Constituição completa a caracterização da forma de governo do País com o enunciado do princípio democrático. Tem o cuidado de acrescentar que o poder democrático se manifesta tanto pelo seu exercício por representantes eleitos quanto, de modo direito, nos termos que a própria Constituição adiante prevê. Sim, a Constituição segue o modelo da chamada democracia semidireta, na qual o elemento representativo é contrabalançado pela tomada de certas decisões pelo povo de modo direto e imediato" (Ferreira F. ${ }^{\circ}$, M.G., Comentários à Constituição de 1988, São Paulo, Saraiva, 1990, v. 1) (aqui se grifou). "De fato, o exercício moderno da democracia se dá em grande parte pela sua modalidade indireta, isto é: ao povo se reserva tão-somente o direito de escolher os seus representantes. É neste momento que o eleitor exerce seu ato político capital ... Não há qualquer viabilidade dentro da hora atual de o povo participar diretamente da decisão política ... É certo que, em pequena escala, esta manifestação 
Tratando-se, por exemplo, da questão da ação civil pública, portanto da concretização de um direito fundamental por meio de um remédio constitucional, a análise da questão mostra-se imprescindível porque, em geral, no evolver do debate esquecem-se os contendores, ancorando seus argumentos em princípios préconstitucionais ou na democracia como modelo, da lição bem lançada pelo ilustre constitucionalista José Joaquim Gomes Canotilho: ${ }^{3}$ "como conceito-chave da Constituição, como princípio estruturante fundamental, o princípio democrático só pode compreender-se como princípio constitucionalmente conformado (Verfassugsgemäss) ... Uma compreensão metodológica e autônoma do princípio democrático constitucional tem de considerar como ponto de partida normativo a sua concreta conformação constitucional", não se permitindo perder no emaranhado de - muitas vezes ignoradas "deduções apodíticas sobre uma pretensa ratio essendi do princípio democrático".

Discorrendo sobre a representação política, malgrado circunscrevendo-a ao âmbito das instituições legislativas, Paolo Biscaretti di Ruffia ${ }^{4}$ the concede a natureza de representação de interesses em contraposição à representação de vontades, vista sob o ângulo do direito privado: "la representación política tiene en cuenta... intereses generales de toda la colectividad popular tal como vienen a resultar de las fuerzas sociales y políticas que en ella se nueven, de las corrientes de pensamiento que en ellas se determinan y de las variadas propuestas de gobierno que se formulan y sostienen ... Y, por esto, es eminentemente representación de intereses generales o políticos ... Un sujeto actúa en nombre proprio, pero en interés de outro". ${ }^{5}$

direta torna-se possível, o que será visto mais adiante" (Bastos, C. \& Martins, LG. da S., Comentários à Constituição do Brasil, São Paulo, Saraiva, 1988, v. 1) - (aqui se grifou).

3. Direito Constitucional, Coimbra, Almedina, $4^{\text {a }}$ ed., 1986.

4. Derecho Constitucional, Trad. Verdú, P.L., Madrid, Tecnos, $2^{\mathrm{a}}$ ed., 1982.

5. Com relação à natureza diversa da representação no âmbito do direito privado, poder-se-á consultar Gomes, O., Introdução ao Direito Civil, Rio de Janeiro, Forense, $6^{\mathbf{a}}$ ed., 1979. Neste âmbito, cumpre salientar que a representação legal portanto independente de manifestação de vontade do representado, somente se admite em situações excepcionais, "diante da impossibilidade jurídica das pessoas incapazes proverem seus próprios interesses" De resto, a representação legal se circunscreve ao "campo do direito de família, pessoal ou patrimonial", ou na subordinação ao interesse do grupo (família, categoria profissional) caso em que, a rigor, a representação é dada à associação ou corporação profissional, perfazendo-se a manifestação de vontade na origem; escolha dos representantes pelos consociados - ou ao de terceiros (falência, concordata). 
O fundamento jurídico de tal representação - prossegue o eminente catedrático de Pavia - qualifica-se, "de ordinario, según el procedimiento electoral empleado para la formación de la Cámara". Isto muito embora reconhecendo o caráter de insuficiência e de prescindibilidade da eleição, uma vez que, no concernente aos requisitos de subsistência de tal representação legal e necessária, "es preciso reconocer que no se há encontrado hasta ahora un procedimiento eficaz distinto del electivo, realizado en un ambiente de verdadeira libertad".

É evidente que somente se pode assumir tais insuficiência e prescindibilidade de um ponto de vista extraconstitucional, pois, para empregarmos o raciocínio kelseniano ${ }^{6}$ - malgrado, neste ponto, evidentemente tautológico ${ }^{7}$-, "sob a condição de pressupormos a Grundnorm: devemos conduzir-nos como a Constituição prescreve, quer dizer, de harmonia com o sentido subjetivo do ato de vontade constituinte, de harmonia com as prescrições do autor da Constituição. A função desta Grundnorm é tornar racional a validade objetiva de uma ordem jurídica positiva, isto é, das normas, postas através de atos de vontade humana, de uma ordem coercitiva globalmente eficaz, quer dizer, interpretar o sentido subjetivo destes atos como seu sentido objetivo". Assim, da perspectiva normativoconstitucional, permite-se estabelecer o silogismo -razão de validade de uma norma positiva: "a premissa maior é uma norma considerada como objetivamente válida por força da qual devemos obedecer aos comandos de uma determinada pessoa, quer dizer, nos devemos conduzir de harmonia com o sentido subjetivo destes atos de comando; a premissa menor é a afirmação do fato de que essa pessoa ordenou que nos devemos conduzir de determinada maneira; e a conclusão, a afirmação de validade da norma". Eis, portanto, o círculo de pressuposição da Grundnorm.

O que cria, aqui, é um critério normativo a precisar convenientemente a responsabilidade política dos que se desejam representantes perante a coletividade: "garantia muy eficiente para los fines del mantenimiento de la mencionada homogeneidad de interes. $Y$ dada que el pueblo elige y envia a la Asamblea representativa a aquellas personas, en la convicción de que representan y tratan de realizar los intereses generales afirmados en las corrientes de pensamiento y en los programas políticos, de los quales se han declarado 1979.

6. Kelsen, H. Teoria Pura do Direito, trad. Machado, J.B., Coimbra, Arménio Amado, $5^{\mathbf{a}}$ ed.,

7. Attié Jr., A. "O direito constitucional como processo", in Revista da Escola Paulista da Magistratura, São Paulo, abril/maio de 1993. 

proposta de Defensoria-Geral da Justiça

exponentes - entonces bien puede admitirse que, con tal significado más genérico, se hable de mandato político en las elecciones y que se califiquen diputados en el Parlamiento a los elegidos".

A eleição, portanto, mostra-se saudável mecanismo a prevenir os já conhecidos malefícios da idéia tão-sedutora para os Estados autoritários - da chamada representação orgânica ou institucional, empregada, "sin recurrir a procedimientos electorales ... con la mira de demostrar la possibilidad para algunos componentes calificados de los distintos grupos sociales (en los cuales apareceria espontaneamente organizado el pueblo...) de interpretar con competencia específica las necesidades particulares, aparte de cualquier elección directa por los consociados".

A Constituição Federal fixa a eleição como o direito político por excelência: "todos aquellos que gozan de derecho electoral forman parte del cuerpo electoral, y la función de los mismos se realiza...se presenta como una manifestación de autogobierno reconocido a la correspondiente colectividad".

Implica, deste peculiar modo, a democracia como princípio normativo ao elemento representativo qualificado pelo sufrágio.

Vale a pena, neste aspecto, acompanhar a preleção do eminente professor de Coimbra: "o princípio democrático, constitucionalmente assegurado, é mais do que um método ou técnica de os governantes escolherem os governados [sic]. Como princípio normativo, considerado nos seus vários aspectos políticos, econômicos, sociais e culturais, ele aspira a tornar-se impulso dirigente de uma sociedade ... Há um objectivo a realizar através da democracia ... Só encarando as várias dimensões do princípio democrático ... se conseguirá explicar a relevância dos vários elementos que as teorias clássicas procuravam unilateralmente transformar em ratio e ethos da democracia. Designadamente: $\{1\}$ o princípio democrático acolhe os mais importantes postulados da teoria democrática representativa órgãos representativos, eleições periódicas, pluralismo partidário, separação de poderes; $\{2\}$ o princípio democrático não ignorou ser hoje o problema fundamental da democracia o de estruturar processos que ofereçam aos cidadãos efectivas 'chances' de aprender a democracia, participar nos processos de decisão, exercer controle crítico na divergência de opiniões, produzir inputs políticos democráticos. É para este sentido participativo que aponta o exercício democrático do poder, a participação organizada do povo e o reconhecimento 
constitucional da participação directa e activa dos cidadãos como instrumento fundamental da consolidação do sistema democrático".

As considerações do professor Gomes Canotilho amoldam-se, sem necessidade de esforço de migração, ainda mais à estrutura de nossa Constituição, quando respeitantes à categoria da representação: "a Constituição...não se baseia em princípios políticos formais ... A representação, como elemento constitutivo do princípio democrático é democrática neste sentido: ao pressupor um direito de voto geral e igual, ao assentar num sistema partidário democrático do poder, ao possibilitar a formação de governos com legitimidade democrática" Para concluir, de forma lapidar: "o elemento representativo, sem misticismo ou desgraça, é um instrumento funcional para legitimar órgãos de soberania de um Estado democrático". 8

O princípio representativo, bem assim, por determinação constitucional, exige o direito de voto o "sufrágio geral, igual, directo, secreto e periódico"

Para arrematar: não se concebe representação no âmbito dos direitos políticos dissociada da eleição.

"La Souveraineté ne peut être réprésentée, par la même raison qu'elle ne peut être aliénée; elle consiste essenciellement dans la volonté générale, et la volonté ne se réprésent point: elle est la même, ou elle est autre; il n'y a point de milieu. Les députés du peuple ne sont donc ni ne peuvent être ses réprésentants ... L'idée des Réprésentants est moderne: elle nous vient du Gouvernement féodal, de cet inique et absurde Gouvernement dans lequel l'espece humaine est dégradée, et où le nom d'homme est dans deshonneur".

A distinção entre direitos fundamentais e garantias remonta a Rui Barbosa," ao separar as "disposições meramente declaratórias, que são as que imprimem existência legal aos direitos reconhecidos, $e$ as disposições

8. Ob. cit.

9. Comentários à Constituição Brasileira, São Paulo, Saraiva, 1932, v. 1, 2 e 6; República: Teoria e Prática, Petrópolis/Brasília, Vozes/Câmara dos Deputados, 1978. 
assecuratórias, que são as que, em defesa dos direitos, limitam o poder. Aquelas instituem os direitos; estas, as garantias; ocorrendo não-raro juntar-se, na mesma disposição constitucional, ou legal, a fixação da garantia, com a declaração do direito".

Comportam as garantias uma acepção ampla e outra estrita. ${ }^{10}$ Entendidas de maneira extensa, seriam, ainda no verbo de Rui, "acima de tudo as providências que, na Constituição, se destinam a manter os poderes no jogo harmônico das suas funções, no exercício contrabalançado e simultâneo das suas prerrogativas. Dizemos, então, garantias constitucionais no mesmo sentido em que os ingleses falam nos freios e contrapesos da Constituição". No sentido mais específico, apostilava o constitucionalista da República à Constituição de 1891, chamam-se, "primeiramente, as defesas postas pela Constituição aos direitos especiais do indivíduo. Consistem elas no sistema de proteção organizado pelos autores da nossa lei fundamental em segurança da pessoa humana, da vida humana, da liberdade humana".

O ilustre professor Manoel Gonçalves Ferreira Filho, titular da Universidade de São Paulo, acrescenta à classificação barbosiana o fato de também se poderem chamar garantias os remédios constitucionais: "ações que servem especialmente à proteção dos direitos fundamentais"

A Constituição Federal de 1988 abriga, sob a rubrica "Dos direitos e deveres individuais e coletivos": direitos e garantias.

Dentre estas, as que nos interessam, aqui, mais de perto, são as que se constituem em remédios constitucionais.

$\mathrm{O}$ art. $5^{\circ}$ refere o habeas-corpus (inciso LXVIII), o mandado de segurança (inciso LXIX), o mandado de segurança coletivo (inciso LXX), o mandado de injunção (inciso LXXI), o habeas-data (inciso LXXII) e a ação popular (inciso LXXIII).

De maneira bastante insólita, o constituinte optou por afastar do leitor da Lei Fundamental, do cidadão, portanto, a visão da ação civil pública ao lado dos demais remédios constitucionais muito embora como tal se caracterize -, deslocando sua regulação para o art. 129, inciso III, classificando-a como função institucional do Ministério Público.

10. Comentários cit. 
Fê-lo malgrado o critério extenso de fixação da legitimação para a sua propositura, consagrado desde 1985 , no art. $5^{\circ}$ da Lei n. 7.347.

Ainda, o constituinte parece ter relegado a um plano secundário a legitimação da União, Estados, Municípios, autarquias, empresas públicas e, sobretudo, das fundações e associações (art. $5^{\circ}$ cit. da Lei que disciplina a ação civil pública cit.), ao explicitar tais sujeitos como "terceiros" não-impedidos pela legitimação que parece ter entendido como principal - do Ministério Público.

Ora, a originalidade de nossa atual Constituição consiste não apenas no afastamento de uma garantia de sua, por assim dizer, comunhão com as demais, ${ }^{11}$ mas sobretudo em inverter a posição de representantes e representados na legitimação para a sua efetivação, valorizando aqueles em detrimento destes, ao suprimir ao contrário do critério para todos os demais remédios o rol dos legitimados, encobrindo-os sob a denominação "de terceiros"

A ação popular é concedida a "qualquer cidadão".

A qualidade subjetiva para agir é, também, ilimitada no que se refere ao habeas-corpus, ao habeas-data e ao mandado de segurança.

A mesma ilimitação deveria ser estendida ao mandado de injunção, uma vez que alude à inviabilidade do exercício de direitos, legitimando todo sujeito que se encontre em tal situação, pela ausência de regulamentação de disposição constitucional, sendo o espírito da injunction avesso a que o legislador destinatário ou sujeito passivo da determinação constitucional - restrinja o âmbito de proteção do cidadão.

11. O que gera equívocos na doutrina, onde se parece olvidar a natureza da ação civil pública, deixando de estudá-la em sua relação com os demais remédios constitucionais. Desloca-se sua análise ao instante em que se introduz as funções essenciais ao Poder Judiciário. Assim, em Ceneviva, W., Direito Constitucional Brasileiro, São Paulo, Saraiva, 1989; Silva, J.A. da, Curso de Direito Constitucional Positivo, São Paulo, Revista dos Tribunais, $6^{\mathbf{a}}$ ed., $2^{2}$ tiragem, 1990; Bastos, C.S.R., Curso de Direito Constitucional, $11^{2}$ ed., São Paulo, Saraiva, 1989. A questão se apresenta de gravidade intensa, uma vez que tais livros são empregados para a formação dos estudantes. A honrosa exceção, aqui, cabe ao professor Manoel Gonçalves Ferreira Filho, que tratou, em seu Curso de Direito Constitucional, $17^{\mathrm{a}}$ ed., São Paulo, Saraiva, 1989, que não se deixou seduzir pela ordem de disposição escolhida pelo constituinte, vindo a tratar da ação civil pública no capítulo destinado aos remédios de direito constitucional: "a ação civil pública, embora não-prevista no Título II da Constituição... alinha-se às demais garantias instrumentais dos direitos constitucionalmente deferidos ... Constitui, ao lado da ação popular, meio de defesa e proteção do interesse público". Os malefícios da opção do constituinte se revelam, de maneira ainda mais a se lamentar, nos manuais dedicados à população, em geral, v.g.: Cotrim, G.V., Acorda Brasil - o que você deve saber sobre a Constituição, São Paulo, Saraiva, 1989. 

proposta de Defensoria-Geral da Justiça

Enfim, o mandado de segurança coletivo tem estabelecidas, no próprio texto constitucional, de maneira expressa, em face de sua ratio essendi particular, as pessoas legitimadas (alíneas a e $b$ do inciso LXX cit.).

A ausência de referência à ação civil pública no art. $5^{\circ}$ e a forma de sua introdução no art. 129 (dispositivo que complementa a definição do Ministério Público, posta no art. 127), contudo, abrem espaço à indagação de seus fundamento, validade e eficácia, enfim, a uma hermenêutica crítica, embasada no princípio democrático, qualificado, como aqui se fez observar, pelo elemento representativo, cuja legitimidade se circunscreve, com férrea necessidade, à eleição.

A Constituição parece querer indicar que o Ministério Público representaria - em primeiro lugar pela incumbência de defendê-los, e, em segundo lugar, por caber-lhe a promoção de sua proteção, por meio do inquérito e da ação civil pública - os "interesses sociais e individuais indisponíveis" (na redação do art. 127) ou o "patrimônio público e social" o "meio ambiente" e "outros interesses difusos e coletivos" (nos termos do inciso III do art. 129).

Tais dispositivos esboçam, desde logo, ao intérprete, a imagem da tentativa de assimilação entre a instituição que se deseja permanente - e os interesses - alçados à indisponibilidade.

Essa assimilação, a toda evidência, consagra-se na representação.

A norma fixa um caso de representação pela via do processo, que se diz legitimação.

Indaga-se, porém, se a tal legitimação, de origem constitucional, corresponde, no plano material, a legitimidade, cuja exigência também se estabelece na Constituição, em norma ou princípio de hierarquia superior, por dizer respeito à própria conformação das instituições que se desejam representativas, ao receberem o cometimento de funções oriundas da soberania. ${ }^{12}$

12. A unidade da Constituição, fizemos observar, estabelece-se como unidade hierárquiconormativa, na feliz expressão do professor Gomes Canotilho. Como bem salienta, todavia, "sendo a Constituição uma estrutura de tensão e não se podendo transformar uma lei constitucional em 'código' exaustivo da vida política, o princípio da unidade da Constituição é igualmente um princípio de interpretação" (ob. cit.). Daí a necessidade de se construir, com base em metódica tipologia dos princípios e das normas, a estrutura sistêmica constitucional: que indique a superação dos conflitos e tensões pelo estabelecimento da correta hermenêutica, adequando as normas aos princípios, sempre imanentes, que as conformam de maneira normativa e exegética. Neste sentido, os princípios se beneficiam de "uma objetividade e presencialidade normativa que os dispensa de estarem consagrados expressamente em qualquer preceito particular ... carecem de uma mediação semântica mais intensa, dado a sua 'idoneidade normativa irradiante' ser, em geral, acompanhada por uma menor densidade concretizadora (por e.: o princípio democrático pode ser esgrimido como 
A Constituição, ao consagrar a representação política, como forma principal do exercício do poder político, diz-nos o professor Gomes Canotilho, ${ }^{13}$ "já aponta para a inadmissibilidade do modelo puro e simples da 'democracia identitária'. O postulado da identidade (entre governantes e governados) anda historicamente associado à sua própria subversão, ou seja, a pretensas identidades histórico-espirituais entre 'povos' e 'Führers', expressas através de plebiscitos ou decisões aclamatórias". Mostra-se refratária a "qualquer adesão a um decisionismo identitário, místico e existencial ... A representação, constitucionalmente consagrada, é um processo normativo e não uma manifestação existencial".

Com efeito, se a sociedade é fragmentária dividida por um semnúmero de razões, de ordem social, econômica, cultural, etc., ${ }^{14}$ que se refletem e realizam também no nível político a Constituição não poderia, fechando os olhos para a realidade, pretender dissolver as diferenças na construção de uma identidade artificial. Sob pena de, desconsiderando o princípio democrático, consagrar seu antípoda: o regime totalitário, único que se permite, por meio de normas vagas,

princípio de interpretação, mas, em geral, ele está concretizado noutras normas da Constituição)". Daí a classificação que o constitucionalista oferece: princípios jurídicos fundamentais; princípios políticos constitucionalmente conformadores; princípios constitucionais impositivos e princípiosgarantia. Aqui, o princípio democrático desponta - pela objetivação histórica - como cerne político de uma constituição política, sua imposição fixando a maior garantia da permanência de uma consciência jurídica construtiva, voltada à recuperação da capacidade política original.

13. Ob. cit.

14. A respeito, cite-se insuspeito sociólogo: "as chances de vida nunca são igualmente distribuidas. Não conhecemos nenhuma sociedade na qual todos os homens, mulheres e crianças tenham as mesmas prerrogativas e gozem dos mesmos provimentos. Não conhecemos sequer uma em que todos tenham o mesmo status ... A sociedade é necessária porque pessoas diferentes têm de criar instituições comuns para sobreviver e melhorar de vida ... Não precisamos persistir na questão das desigualdades naturais entre os humanos aqui, a não ser para dizer que os interesses e motivaçōes das pessoas diferem, e que, em todas as sociedades, encontraram maneiras de organizar estas diferenças sob formas que envolvem tanto coordenação quanto subordinação. A divisão do trabalho coordena diferentes tarefas para um efeito comum; a estratificação social subordina alguns a outros, ao aplicar uma escala de valores na qual alguns são posicionados abaixo de outros ... A distribuição desigual das chances de vida é um resultado das estruturas de poder ... A 'sociabilidade insociável' do homem é o ferrão que produz os antagonismos dos quais o progresso flui, incluindo mais chances de vida dentro de um contrato social aperfeiçoado. $O$ poder gera não apenas a desigualdade mas, pelo mesmo motivo, conflito ... A origem do conflito de classe, então, é encontrada nas estruturas de poder, as quais não possuem mais a qualidade absoluta de hierarquia entrincheirada. $O$ assunto do conflito de classe são as chances de vida. Mais precisamente, é a distribuição desigual das chances de vida ... Passamos progressivamente das desigualdades qualitativas para as desigualdades quantitativas..." (Dahrendorf, R.; Conflito social moderno. Trad. Aguiar, R. \& Rocha, M.A.E. da, São Paulo, Jorge Zahar/EDUSP, 1992). 
declarar a identidade de interesses do povo (considerado em abstrato), assimilando as figuras dos representantes e representados.

A norma constitucional, em síntese, consubstanciada nos arts. 127 e 129, não pode ser considerada como uma adequação pura e simples mística, porquanto oriunda de uma mera enunciação normativa - entre o dever do órgão estatal (de defender, de proteger) e os interesses que enumera: indisponíveis, coletivos, difusos.

Mormente porque falece ao órgão representante a legitimidade original (art. $1^{\circ}$, parágrafo único, da Constituição). $\mathrm{O}$ órgão a quem incumbe a defesa e a proteção de tais interesses, representando-os em Juízo, está destituído do mandato político, necessário à consecução dos direitos políticos.

Daí o fato de ser recorrente, em ações, a alegação de ilegitimidade ativa do Ministério Público.

Alegação, entretanto, originária de uma confusão entre o direito processual - para o qual é bastante a legitimação abstrata e o direito material.

Este último designa o cerne da ação: é o próprio objeto de uma ação que se deseja remédio constitucional.

Está legitimado à representação material dos interesses que afirma defender?

Nos termos dos arts. 127 e 129, ou seja, no plano exclusivamente processual, a resposta parece afirmativa.

Entretanto, no plano material, parece faltar-lhe a representação, por ilegitimidade.

"L'élection est la base du modèle démocratique. Elle constitue un procédé de désignation des gouvernants opposé à l'hérédité, à la cooptation ou à la conquête violente, qui sont les moyens autocratique ... En pratique, le développement de l'élection s'est fait cependant de façon continue, par la logique même du système ... Les élections libres ainsi définies ont paru dangereuses à certaines époques ... Certaines théories ingénieuses de la représentation populaire ont donc été inventées, afin de limiter la portée des élections. Par ailleurs, le rôle des élections reste limité..." 
A democracia, na definição moderna, consoante bem expressa Maurice Duverger, ${ }^{15}$ é o regime em que os cidadãos governam por si mesmos ou por intermédio de governantes eleitos. ${ }^{16}$

Qualquer elemento autocrático poderá levar a abalar a solidez democrática do sistema político, transformando-o, nas palavras do eminente cientista político e constitucionalista deste século, em uma démi-democratie.

Daí a existência do relógio da legitimidade.

A legitimidade é antiga questão posta ao debate da política e do direito constitucional.

Sua formulação mais radical talvez tenha sido dada no manuscrito que o jovem jurista La Boétie confiou a seu amigo Montaigne: ${ }^{17}$ "gostaria apenas de entender como pode ser que tantos homens, tantos burgos, tantas cidades, tantas nações suportam às vezes um tirano só, que tem apenas o poderio que eles lhe dão, que não tem o poder de prejudicá-los senão enquanto têm vontade de suportá-lo, que não poderia fazer-lhes mal algum senão quando preferem tolerá-lo a contradizê-lo", ao lamentar, "com conhecimento de causa", ser um "extremo infortúnio estar-se sujeito a um senhor, o qual nunca se pode se certificar de que seja bom, pois sempre está em seu poder ser mau quando quiser; e em ter vários senhores, quantos se tiver quantas vezes se é extremamente infeliz"... 18

A legitimidade corresponde à indagação da razão e da justificação da submissão política, considerada a sua investigação não mais no sentido, digamos, revolucionário laboétiano, senão no da Herrschaftssoziologie de Max Weber. ${ }^{19}$

Neste aspecto, acreditava o sociólogo alemão que nenhuma forma de dominação contentar-se-ía com a obediência forma de submissão exterior pela razão, por oportunidade ou por respeito - mas procuraria sempre despertar nos

\section{Institutions politiques et droit constitutionnel, $16^{\mathrm{a}}$ ed., Paris, PUF, 1980, v. $1^{\circ}$} élus".

16. "un régime où citoyens gouvernent par eux-mêmes ou par l'intermédiaire de gouvernants

17. Le discours de la senvitude volontaire. (c. 1552).

18. Vício inominável da servitude: "doncques quel monstre de vice est cecy, qui ne merite pas ancore le titre de couardise, qui ne trouve point de non asses vilain, que la nature desadvoue avoir fait, et la langue refuse de nonmer?"

19. Economia e Sociedade. Trata-se a sociologia política de Weber de uma sociologia da dominação: "a dominação está no âmago do político e que o agrupamento político é antes de mais nada um agrupamento de dominação", na glosa de Freund, J., Sociologia de Max Weber. Trad. Castro e Costa, J.C. de, $3^{2}$ ed., Rio de Janeiro, Forense Universitária, 1980. 

proposta de Defensoria-Geral da Justiça

membros "a fé em sua legitimidade, ou seja, transformar a disciplina em adesão à verdade que ela representa". ${ }^{20}$ Daí sua concepção dos três tipos de legitimidade, entre os quais nos interessa mais de perto o que refere a dominação racional: "tem por fundamento a crença na validade dos regulamentos estabelecidos racionalmente e na legitimidade dos chefes designados nos termos da lei".

As outras duas formas de legitimidade, a contrario sensu, acentuam o caráter da primeira: "no caso da dominação tradicional, a autoridade não-pertence a um superior escolhido pelos habitantes do país... $O$ que falta numa administração dessas é a competência controlada segundo critérios definidos...a hierarquia racional ... A dominação carismática constitui tipo excepcional de poder político porque deturpa os usos da vida política ordinária... Seu fundamento é quase emocional e não-racional" 21

Interpretando, de modo rígido e preciso, a concepção weberiana da autoridade-legitimidade racional, o professor Jürgen Habermas ${ }^{22}$ salienta a necessidade do cumprimento de duas condições para o seu reconhecimento: "( $a$ ) a ordem normativa precisa ser estabelecida positivamente; $e$ (b) aquelas legalmente associadas precisam crer na sua legalidade, isto é, no processo correto formalmente para a criação e aplicação das leis".

Portanto, a crença na legalidade não se legitimiza per se: "o positivismo legal requer, em vez disto, um consenso geral, fundamentado numa orientação racional valorativa".

Ou, de maneira mais contundente: "a legalidade pode criar legitimação quando, e apenas quando, os fundamentos possam ser apresentados para mostrar que certos procedimentos formais obedeceram as pretensões materiais e empíricas sob certas condições institucionais limítrofes". Para concluir: "a maneira inquestionável, pela qual uma norma nasce, isto é, a forma legal de um procedimento, só garante, enquanto tal, que as autoridades providas pelo sistema político, e que são abastecidas com certas competências e reconhecidas enquanto tais trazem em si a responsabilidade da lei válida. Mas estas autoridades são parte

\section{Freund, J., ob. cit.}

21. Ob. cit., aqui se grifou, para salientar os critérios eletivo e de controle da autoridadelegitimidade racional.

22. A crise de legitimação do capitalismo tardio. Trad. Chacon, V., Rio de Janeiro, Tempo Brasileiro, 1980. 
de um sistema de autoridade, que precisa ser legitimado enquanto um todo, se a pura legalidade tiver de contar enquanto uma indicação de legitimidade. Num regime fascista, por exemplo, a forma legal dos atos administrativos pode ter, no máximo, uma função mascarante. Isto demonstra que só a forma legal técnica, a pura legalidade, não são aptas a garantir o reconhecimento, a longo prazo, se o sistema de autoridade não puder se legitimar independentemente da forma legal de exercer autoridade". ${ }^{23}$

A fórmula da legitimidade, em conclusão, não pode ser assumida como mero produto de decisões, verbia gratia, no raciocínio que admite uma prorrogação hermenêutica do conflito entre as normas constitucionais, assumindo a Constituição como um conjunto de fragmentos, a terem fundamento per se id est, apenas por fazer parte do texto legal.

O exemplo do fascismo é recorrente. Com razão, uma vez que o decisionismo deriva da teoria do jurista que veio a fundamentar as reformas constitucionais que levaram à hegemonia do nacional-socialismo na Alemanha, Carl Schmitt. $^{24}$

De qualquer perspectiva, todavia, seguindo ainda aqui os conceitos de Weber, seja do ponto de vista da racionalidade formal do direito, seja de sua racionalidade material, para o nosso caso concreto, a legitimidade está condicionada pelo critério constitucional do princípio democrático. ${ }^{25}$

\section{Idem, ibidem.}

24. Cujo discípulo, neste passo, tem sido citado, sem cautela alguma, pelos juristas contemporâneos, como se estivesse sua teoria guardada de qualquer contaminação ideológica. Assim, na passagem de uma de suas obras: "a positivação do direito significa que a validade legal legítima pode ser obtida, em qualquer conteúdo dado, para que isto se realize através de uma decisão que confere validade em relação à lei e a qual pode tomar dali a sua forma de validade. $O$ Direito positivo é válido por causa de decisões" (Luhmann, N., Soziologische Aufklärung, apud Habermas, J., ob. cit.).

25. Parece de extrema importância referir aqui um texto de 1979 do professor Fábio Konder Comparato, em que a intuição do ponto crucial da questão se revela: "nos primórdios da República, entendeu-se de suprimir a ação popular, sob o pretexto de que o interesse público deve ser protegido judicialmente por iniciativa do Ministério Público, e não do particular. Foi um grave erro ... porque se ignorou a grande virtude desse tipo de ação de suscitar o empenho popular pela fiscalização direta do Poder Público, num país em que a sociedade civil sempre foi curatelada" Mais à frente, sobre uma proposta esboçada de reformulação do Ministério Público: "sugeriria que se começasse pela eleição popular do chefe do Ministério Público, tanto federal quanto estadual" ("Segurança e Democracia" in Lamounier, B. et al., Direito, Cidadania e Participação, São Paulo, T.A. Queiroz editor, 1981 - aqui se grifou). 

proposta de Defensoria-Geral da Justiça

"L'esperienmza contemporanea ̀̀ testimone di un fenomeno chi sembrerebbe presentari momenti di aspra contraddizione. Da un latto, le istituzione de democrazia rappresentativa, espressione del pensiero giuridico liberale, appaiano scosse da una crisi da molti ritenuta irreversibile ... Dall'altro lato, emerge invece una domanda, intensa e consistente, di participazione popolare proprio a quelle strutture politiche, economiche e sociali di cui si riconosce crisi $e$ insufficienza ... Il proprium della partecipazione sta nel conoscere e nel intervenire e quindi, anzitutto, nel prendere parte al momento decisionale, nel farsi da oggetti soggetti di decisione, da destinatari autore delle scelte. Nel partecipare però non c'è solo questo, perché il prendere parte, l'essere presente, responsabile sono azioni que non si esauriscono necessariamente nel momento decisionale, ma che possono benissimo realizzarsi in un momento successivo: così, il decidere $\grave{e}$ participare, ma anche il controllare lo $\grave{e}^{\prime \prime}$.

Notável autor italiano estabeleceu séria restrição à atuação do Ministério Público na representação dos interesses coletivos e difusos. ${ }^{26}$

Os interesses coletivos, com efeito, constituem-se em um tertium genus, que vem a mediatizar a separação moderna entre o público e o privado, onde por público, explica-nos outro clássico, ${ }^{27}$ "entende-se aquilo que é reservado ao povo ou ao Estado", enquanto por privado, prossegue, "compreende-se aquilo que pertence à livre disponibilidade do individuo que dele é 'titular'".

26. Vigoriti, V., Interessi Collettivi e Processo - la legitimazione ad agire, Milano, Giuffrè, 1979: os integrantes do Ministério Público sentir-se-íam, antes de tudo "penalisti e tendono quindi a considerare le questioni civili di cui devono occuparsi (obbiettivamente, in genere poco stimolanti) come marginali e secondarie nei confornti di quelle penali ... La presenza del pubblico ministero nel processo civile è espresione di quel modo, superato, di concepire gli interessi e la loro tutela che, per classica rappresentazione, fa coninciare lo Stato laddove finisce l'individuo".

27. Cappelletti, M., "Formações sociais e interesses coletivos diante da Justiça civil". in Revista de Processo 5/128-159. Trad. Campos, N.R.P.R. de 
Desta distinção tradicional, resulta o entendimento do processo civil, em regra, como envolvido por relações privadas, de cunho individual, estando, ao contrário, o processo penal imbuído do interesse público.

É, pois, exatamente no processo penal que toma relevo a função do Ministério Público, assim como, excepcionalmente, no processo civil, quando nele se reconhece um elemento público, quando vem a estar legitimado a agir ou a intervir, "enquanto representante do Estado, que é 'titular' do direito público"

A intervenção do parquet, portanto, está historicamente implicada nesta summa divisio, nesta might cleavage, ${ }^{28}$ "irreparavelmente superada diante da realidade social de nossa época, que é infinitamente mais complexa, mais articulada, mais 'sofisticada'": explicita o professor Cappelletti.

$\mathrm{O}$ advento dos interesses coletivos destrói o antigo ideal da iniciativa processual monopolística centralizada nas mãos de um único sujeito - seja o indivíduo, seja o órgão encarregado de tutelar aqueles interesses. ${ }^{29}$

Coube a um expoente do parquet anunciar a inabilitação do órgão a representar uma classe, um grupo de cidadãos ou de interesses. ${ }^{30}$

28. Observe-se que, até o advento da Constituição de 1988, a função do Ministério Público estava ligada ao Poder Executivo (art. 94 e ss. da Emenda Constitucional n. 1 de 1969). A Constituição de 1891 ( $\S 2^{\circ}$ do art. 58), a rigor, é a única em que se pode considerar a ligação, pela origem do Procurador Geral, entre o Ministério Público e o Poder Judiciário. Isto porque, malgrado a inserção da regulação do órgão no capítulo reservado ao Judiciário, nas Constituições de 1937 (art. 99 e ss.), 1946 (art. 125 e ss.) e 1967 (art. 137 e ss.), a sua índole executiva permanece. Na Constituição de 1934, o Ministério Público aparece entre os órgãos de cooperação nas actividades governamentaes (art. $95 \mathrm{e}$ ss.). Observar-se-á, afinal, que a atual Constituição prevê a nomeação do Procurador Geral da República se perfaz por ato complexo: escolha do Presidente da República e aprovação do Senado Federal, sendo que deverá recair dentre os integrantes da carreira. O Procurador Geral da República é considerado o chefe do Ministério Público da União. No Estado de São Paulo, a nomeação se dá pelo Governador, que escolhe, discricionariamente, um dos indicados em lista tríplice estabelecida pelo próprio órgão, na forma da lei complementar (art. 94 da Constituição Estadual).

29. O mesmo processualista observa que, "já sob o anterior regime corporativo, diversas entidades eram oficialmente legitimadas a fazer-se representar - e talvez representantes exclusivos, como também na França sob o regime de Vichy ... Mas o fenômeno não escapava da rígida regra dicotômica por nós indicada. Tratava-se do fato de entidade de Direito Público (se não exatamente de órgão do Estado); eram, em suma, nada mais que a longa manus do Estado, e a representação de sua parte nos interesses de categoria não escapava ao aut aut público-privado. A única diferença era constituída pelo fato de que, mesmo que fosse confiada ao órgão a tutela geral dos interesses públicos o Ministério Público - a tutela daqueles interesses era confiada a órgãos especiais, uma espécie de Ministério Público especial ou especializado"

30. Jegu, J., "Le rôle du Ministère Public dans le Procès Civil" in IX Congresso Internacional de Direito Comparado apud Cappelletti, M., ob. cit. $\mathrm{O}$ autor foi Produrador Geral de Lyon. 

proposta de Defensoria-Geral da Justiça

O professor Cappelletti ainda refere o caráter hierárquico $e$ de carreira da instituição, entendendo a impossibilidade de florescimento em seu seio de saudável "forma de pluralismo". Lamenta a especialização jurídica dos seus membros, quando a representação e defesa dos interesses coletivos "implicariam conhecimento altamente especializado em matéria contábil, urbanística, ecológica, química e assim por diante. E conclui: "a segunda solução aquela de confiar a defesa dos interesses coletivos ao Ministério Público (ou por outra análoga 'parte pública'...) está demonstrada de todo inadequada".

A questão da legitimação, no entanto, resolve-se com maior acerto e segurança quando se a vincula à própria essência ${ }^{31}$ dos interesses coletivos: interesses que constituem a verdadeira razão de ser das formações sociais.

Tendo o Estado tomado para si o monopólio da capacidade jurídicopolítica, que veio a denominar de soberania, com o advento da modernidade, buscando, paulatinamente, destruir qualquer corpo que a reivindicasse ou ente que desejasse recuperá-la, é natural que, ao institucionalizar os reclamos pela juridicização dos interesses difusos e coletivos, resguarda-se seu controle sobre o renascimento, a emergência dos corpos intermediários. ${ }^{32}$

A desconfiança desses tipos de organização parece ter-se eternizado: a Constituição, observe-se, não hesita em conceder ao Ministério Público a legitimação e a Lei n. 7.347, de maneira até certo ponto similar, fala com naturalidade deste mesmo órgão, de entidades da Administração direta e indireta, somente se recordando de impor condições quando alude às associações... Isto em um país de carência tradicional de representatividade, de legitimidade.

31. O eminente professor italiano sublinha, aliás: "a interpretaçāo do jurista deve esforçar-se por ser sobretudo una realística adaequatio intellectus ad rem, ao invés de uma absurda adaequatio rei ad ad intellectum".

32. O professor Cappelletti cita, com propriedade o seguinte excerto do trabalho de Max Rheinstein ("The family and the law" in International Encyclopedia of Comparative Law, Tübingen, Chloros, 1974): "com o iluminismo do século XVIII, a visão individualística da sociedade começou a prevalecer. Na Revolução Francesa, a nova ideologia torna-se oficial. A nação deveria ser une et indivisible. $O$ Estado era, enfim, claramente concebido como composto de cidadãos, enquanto os grupos intermediários foram varridos; a mesma municipalidade transformou-se em mera subdivisão do governo estatal. Apenas um grupo intermediário entre o Estado e os cidadãos foi deixado intacto: a familia" Ainda, esta passagem de De Soto, J. ("L'individualisme dans la Jurisprudence du Conseil d'État" in Mélanges offerts à Marcel Waline, Le Juge et le Droit Public, Paris, Librairie Générale de Droit et de Jurisprudence): "traditionellement le Droit français regarde les groupements avec méfiance: la vieille exécration de Rousseau à l'egard des corps intermédiaires qui troublent les rapports entre le Souverain et les citoyens et empêchent la formation de la volonté générale s'allie à la peur de l'État de voir les groupements concurrencer ses activités et créer des féodalités nouvelles" 
Sabemos que a legitimação, no interior do processo, não passa de uma aparência, que visa a solucionar a dicotomia entre a titularidade real do direito questionado e a sua simples alegação, própria da concepção da ação dissociada do direito material: "realmente, considerada a simples afirmação de titularidade do direito questionado, ou de titularidade de situação legitimante ensejadora de inserção, em nome próprio, em lide alheia como suficiente para a legitimidade do autor, se esta alegação não corresponder à realidade, propiciando inobstante, a apreciação do mérito, pelo menos ensejará o surgimento de uma situação aparente, que, embora incompativel com a realidade extra-autos, produz efeitos jurídicoprocessuais". 33

A legitimação consiste, para o brilhante processualista pátrio, "como condição de exercício regular da ação, [em] uma qualidade jurídica que se agrega à parte, habilitando-a a ver resolvida no mérito a lide sib iudice". correspondente processual da legitimidade conhecida da teoria geral do direito: "uma qualidade do sujeito aferida em função de ato jurídico, realizado ou a ser praticado. Qualidade outorgada exclusivamente pelo sistema jurídico e exigível ... Essa qualidade resulta de uma situação jurídica oriunda precipuamente da titularidade de uma relação jurídica ou de uma situação de fato, a qual o direito reconhece efeitos jurígenos" ${ }^{34}$ As características básicas do instituto seriam: "a) a idoneidade jurídica do sujeito, como uma atribuição do sistema, normalmente sem caráter declaratório; b) a necessária vinculação entre essa qualidade e o objeto do ato, com implicações recíprocas indissociáveis; c) o caráter de anterioridade ou contemporaneidade da idoneidade em face do ato a ser praticado, ou das conseqüências a serem suportadas, o que lhe assegura a categoria de pressuposto destes; d) a emergência da qualidade em tela de uma titularidade de relação jurídica, simultânea $e$ qualificante da relação resultante do ato praticado, ou, ainda, de uma situação de fato à qual o sistema jurídico, por razões relevantes de segurança jurídica e tutela à boa-fé, outorga efeitos jurígenos; e) finalmente, a correlação entre legitimidade e eficácia de ato jurídico, com ênfase à característica específica daquela no sentido de assegurar a plenitude dos efeitos deste, no que dependa da legitimidade como pressuposto do ato". ${ }^{35}$

33. Armelim, D., Legitimidade para agir no Direito Processual Civil brasileiro, São Paulo, Revista dos Tribunais, 1979.

34. Id., ibid. $\mathrm{O}$ autor prefere sempre o termo legitimidade a legitimação (v. p. 12).

35. Id., ibid. 

proposta de Defensoria-Geral da Justiça

A titularidade do interesse coletivo e do interesse difuso (como categorias de relevância extrema na configuração jurídico-política da sociedade) pertence à sociedade mesma ou a seus corpos intermediários, em face do pluralismo essencial à convivência democrática, sendo de todo desaconselhável que o Estado venha a pretender unificar as vontades, tornar sua representação indivisível.

Destarte, a previsão constitucional subalterna - do ponto de vista exegético e construtivo -, no mínimo, deve ser aplicada da forma a mais estrita possível, por negar a estipulação constitucional superior do princípio democrático.

Deve-se mesmo indagar da possibilidade jurídica, em face da legitimidade, de se prorrogarem as criações de órgãos públicos de tutela dos interesses coletivos e difusos.

"Dans le anciennes Républiques et même dans les monarchies, jamais le peuple n'eut de réprésentants; on ne conçoit pas ce mot-là. Il l'est très singulier qu'à Rome où les Tribuns étoient si sacrés on n'ait pas même imaginé qu'ils pussent usurper les fonctions du peuple, et qu'au milieu d'une si grande multitude, ils n'aient jamais tenter de passer de leur chef un seul Plebiscite ... Où le droit et la liberté sont toutes choses, les incovéniens ne sont rien. Chez ce cage peuple tout étoit mis à juste mésure: il laissoit faire à ses Licteurs ce que ses Tribuns n'eussent osé faire; il ne craignoit pas que ses Licteurs voulussent le réprésenter"

É evidente que não se resgatará, hoje, em sua radicalidade, o elogio do pensador do Contrato Social à democracia direta.

Entretanto, não se deve fazer ouvidos de mercador às críticas ao sistema representativo, mormente à reivindicação de um necessário controle sobre suas instituições. ${ }^{36}$

Da perspectiva, pois, da representação contemporânea, obrigatoriamente estendida a todos os modos de manifestação do poder, ${ }^{37} \mathrm{o}$

36. Que, como vimos, a Constituição atual coroa.

37. Veja-se a elogiável amplitude do comentário de ilustre jurista José Celso de Mello Filho, ora pontificando no colendo Supremo Tribunal Federal, já a Constituição anterior: "a origem popular do poder acha-se consagrada no parágrafo primeiro do artigo primeiro, que institui o sistema de 
princípio democrático prolonga suas amarras, abarcando também as funções de controle.

A representação implica, em sua concepção moderna, a conjugação de uma ausência e de uma presença: o substituto se apresenta, como imagem mnêmica do substituído. Ao se revelar, o representante oferece a imagem daquele que visa a representar. Aquele faz presente o representado.

Mais, o representante pretende querer em nome do representado: o signo da identidade suplementa a alteridade.

$A$ representação desencadeia uma operação mental complexa e perigosa.

Complexa porque impõe a superação da distância entre dois termos absolutamente antagônicos.

Perigosa por determinar na mente social a idéia da substituição da vontade, tendendo a uma assimilação inverídica - do ponto de vista real e de conhecimento e inaceitável - da perspectiva democrática.

Não é, portanto, à toa, que o conceito de representação também diz encobrimento, dissimulação, encenação.

A legitimidade jurídica serve como medida de controle e limite da potencialidade totalitária da representação.

Ao impor o consentimento, pelo sufrágio universal, o constituinte coibiu qualquer tentativa de exercício de atividade de representação sem consenso, bem como impediu a permanência do exercício do poder, sem alternância, sem a atenção ao pluralismo. ${ }^{38}$

democracia representativa. O povo (conjunto das pessoas físicas dotadas dos atributos da cidadania) é a fonte do poder político. O poder é exercido em nome do povo, pelos representantes por ele investidos no desempenho de um mandato ... O exercício consentido do poder representa o sinal mais expressivo da prática legítima das instituiçōes estatais. O consenso dos governados reveste-se de absoluta essencialidade para legitimar qualquer ordem jurídica e política. Na realidade, o consentimento dos destinatários do poder constitui, em si mesmo, o próprio fundamento da legitimidade. Sem esta, o poder se reduz à força e à mera capacidade de impor e de executar decisões" (Constituição Federal Anotada, $2^{a}$ ed., São Paulo, Saraiva, 1986).

38. "Le pluralisme n'est donc pas simplement une manière nouvelle d'affirmer la liberté d'opinion ou de croyance. C'est un système qui enracine cette liberté dans la strucutre sociale ... Au lieu de retrancher l'individu de la societé pour qu'apparaisse as liberté, le pluralisme l'insère dans son contexte social, seul capable de lui assurer une liberté réelle" (Burdeau, G., Traité de Science Politique, Paris, 1973 , v. $7^{\circ}$ ). 

proposta de Defensoria-Geral da Justiça

Todo o exercício do poder é temporário ("todo poder emana do povo, que o exerce por meio de representantes eleitos') e limitado pela cidadania (art. $1^{\circ}$ inciso II), manifestada de maneira plural (inc. V do mesmo dispositivo).

$\mathrm{Na}$ expressão de minuciosa monografia, "ao ser quebrada a homogeneidade de interesses de que a sociedade liberal se fizera portadora...assiste-se, gradualmente, a um processo de (re)politização da sociedade civil e, por arrastamento, a um progressivo desmoronamento das barreiras outrora apostas na relação indivíduo-Estado. É essa expansão em sentido qualitativo (nãoapenas quantitativo) da estrutura do espaço público que acaba por atirar para a ordem do dia a questão fulcral do pluralismo. Este, no essencial, chama a atenção do jurista para a existência na realidade normada de um complexo de instituições associações ou organizações de pessoas ou de interesses -, como corpos autônomos e voluntários, que se interpõem (:mediatizam) na relação indivíduo-Estado: os grupos pluralistas ... Mas a aceitação da dimensão plural da sociedade significa, ainda, o reconhecimento na realidade normada da existência de uma pluralidade $e$ heterogeneidade de interesses e de valores de que os grupos pluralistas se apresentam objetivamente como os portadores. Expressa, por conseguinte, seja qual for a sua feição, política, econômica, social, cultural ou religiosa, o repúdio por todas as formas autocráticas e totalitárias de exercício do poder. A bom droit, o pluralismo repele todas as formas compulsórias e coercitivas de integração e a fortiori de pretensa identificação entre o indivíduo e o Estado". ${ }^{39}$

Nestes termos, a realidade normada não permite a representação perenizada de interesses sociais, muito menos autoriza a concepção de interesses permanentes supra-sociais, inalcançáveis pelo debate democrático, pelos conflitos $\mathrm{e}$ consensos da pluralidade.

Se tal pluralismo qualificador da representação se encontra presente no instante da tomada das decisões - legais e administrativas - até por maior razão deverá atuar no momento da fiscalização da conformidade dessas decisões ao consenso, à vontade da sociedade expressa por representantes legitimados pela escolha popular.

Disso sabem os norte-americanos, pelo menos desde 1938, como faz recordar o preciso Professor Titular da Universidad Central de Barcelona: "una concepción habitual de la representación política es la que concibe como

39. Queiroz, C.M.M., Os actos políticos no Estado de Direito, Coimbra, 1990. 
transferencia de poder de decisión a unos representantes...Esta sería una concepción restrictiva de representación. Un concepto de representación muy diferente del anterior es el que se deriva de una consideración que se planteó el Tribunal Supremo norteamericano en una nota a pie de página de una sentencia de 1938: si las leyes que restringuen 'aquellos proceso que ordinariamente se espera que produzcan la derogación de la legislación indeseada' debían ser sometidas a un test de constitucionalidad más estricto que las demás. Esta nota a pie de página tuvo enorme trascendencia en la doctrina constitucionalista posterior ... De acuerdo con la concepción implícita en esta sentencia, el proceso de representación política no acabaría com la delegación a los representantes de la facultad de decidir. Tendria también el sentido de un control crítico posterior de la actividad de eses representantes. La participación no terminaría en el momento de depositar el voto, sino que derechos como la libertad de expresión, de asociación o de manifestación estarian situados en un nivel de importancia similar al del sufragio. Este tipo de derechos serían mecanismos participativos suscetibles de producir la derogación de la legislación indeseada ... La concepción abierta considera los procedimientos juridicamente establecidos como instrumentos al servicio de un fin: la transferencia de la voluntad política mayoritaria a las instituciones estatales. Los resultados de estos procedimientos deben ser suscetibles de ser sometidos a crítica ... Esta concepción...valora los mecanismos reales desde el ideal de un proceso de formación de voluntad abierto y pluralista en el que el pueblo no sólo aparece como un cuerpo electoral unitario, sino también en la forma de partidos, movimientos, iniciativas ciudadanas, etc. $Y$ es sensible al hecho de que los actores se encuentran en posiciones desiguales. El resultado de este proceso puede ser integrador o no serlo; pero en cualquier caso, la integración no debe conseguirse por el procedimiento de la represión autoritaria de la disidencia" ${ }^{40}$

"Temos, para nós, essas verdades como evidentes por si próprias: que todos os homens são criados iguais $e$ dotados pelo seu criador de direitos (inerentes e) inalienáveis; que entre estes estão a vida, a liberdade e a procura da felicidade; que para assegurar tais direitos são isntituidos governos entre os homens, os quais

40. Estevez Araujo, J.A., "Desobediencia civil y representación política" in Información y debate, Madrid, 14/15-17, 1991. 

proposta de Defensoria-Geral da Justiça

derivam seus poderes justos do consentimento dos governados ...Desejo, com sincero zelo, uma preservação inviolável da nossa atual Constituição federal, de acordo com o verdadeiro sentido com que ela foi adotada, ou seja, no sentido que foi advogado pelos seus amigos e não pelo que seus inimigos depreenderam, tornando-se, em conseqüência seus inimigos. Oponhome a que se monarquizem os seus lineamentos pelas formas de sua administração ... acabando assim com o princípio eletivo ... Acreditamos...que o homem era um animal racional, dotado pela natureza de direitos e com um sentimento inato de justiça; e que ele poderia ser reprimido das ações errôneas e protegido nas ações diretas por poderes moderados, confiados a pessoas de sua própria escolha, e observar os seus deveres pela dependência de sua própria vontade".

O eremita do Monticello deixou gravadas as, talvez, mais belas páginas de defesa da democracia e das liberdades públicas, no papel que a história lhe reservou de, ao lado de seus compatriotas, fundar o regime de um país independente, composto de homens que se compreendiam livres.

Afirmava, mesmo na condição de mais alto magistrado do Estado, sua crença na difusão do poder: "não é, porém, pela consolidação ou concentração de poderes, mas pela sua distribuição, que se efetiva o bom governo. Se esse grande país ainda não estivesse dividido em Estados, essa divisão deveria ser feita, a fim de que cada um pudesse fazer por si mesmo tudo que lhe diz respeito diretamente, e o que ele pode fazer muito melhor do que qualquer autoridade distante. Cada Estado está, por sua vez, dividido em distritos, que devem cuidar do que se encontra dentro de seus limites locais; cada distrito se divide, ainda, em termos ou vilas, para a direção dos menores detalhes; e cada termo em fazendas que são governadas pelo seu proprietário individual. Se nos deixássemos guiar por Washington quanto à ocasião de semear e à ocasião de proceder à colheita, em breve careceríamos de pão. É por meio dessa repartição de cuidados, que desce, gradativamente, do geral 
ao particular, que a massa de negócios humanos pode ser melhor dirigida, para o bem e a prosperidade de todos". 41

A Constituição americana, iluminada por seus comentários elaborados na lida incessante de busca de construção da nação serviram, no embate das idéias, para forjar o pensamento de uma verdadeira civilização.

O termo civilização, narra-nos Émile Benveniste, ${ }^{42}$ foi pela primeira vez empregado e definido pelo marquês de Mirabeau, na seguinte passagem de texto de 1757: dir-se-á que "a civilização é a suavização dos seus costumes, a urbanidade, a polidez e os conhecimentos, difundidos de maneira que as conveniências sejam observadas e tenham o valor de leis avulsas; tudo isso não me apresenta senão a máscara da virtude e não o seu rosto, e a civilização não faz nada para a sociedade se esta não lhe dá o fundo e a forma da virtude".

A civilização, pois, como virtude social, não se compreende na aparência do bom governo, das boas leis, das boas atitudes. Consagra-se na realidade (não da conveniência de obedecer, mas) da conviç̧ão de que as leis e os atos que são cumpridos resultam da concessão do governo aos que se submetem aos termos e limites do consentimento dos governados.

Nos três termos finais grifados encontra-se o espírito da representação e da legitimidade, que têm a ver com a origem do poder e com o controle de seu exercício.

Postas tais premissas, passo a analisar o aspecto referente à própria legitimação para agir do Ministério Público.

Em seu âmbito, como fizemos notar, pergunta-se da qualificação do autor que o torne hábil a receber uma decisão de mérito.

Deve-se, in casu, interpretar a norma constitucional também de maneira estrita.

Os arts. 127 e 129, e seus incisos, estabelecem dispositivos de natureza meramente processual e, neste sentido, as hipóteses ali previstas não podem ser estendidas, sob pena de negar vigência ao princípio democrático e aos direitos fundamentais.

41. Jefferson, Th., O pensamento vivo de... Trad. Rodrigues. L.B., Martins, s.d.

42. Problemas de Lingüistica Geral. Trad. Novak, M. da G. \& Neri, L., São Paulo, Cia Ed. Nacional/EDUSP, 1976. 

proposta de Defensoria-Geral da Justiça

Admite-se, em síntese, a legitimação entendida como dissociada de sua discutível legitimidade material também para evitar qualquer cerceamento de exercício de direitos, em abstrato.

A primeira indagação, contudo, de mérito, em se tratando de questão atinente ao direito político, é a da adequada representação ${ }^{43}$ dos interesses coletivos.

Como vimos, tal representação inexiste senão em restritos termos da abstração processual, muito menos se mostra adequada.

Explicitemos o argumento, ainda uma vez.

Neste passo, vamos nos socorrer de dois eminentes processualistas, que têm se notabilizado na pesquisa da efetividade da tutela do direito e da instrumentalidade do processo. ${ }^{44}$

É evidente que todo libelo de defesa da Constituição lança raízes na história jurídico-política norte-americana. Mais precisamente, no texto de dois eminentes juristas.

O primeiro deles, cuja originalidade deve ser saudada, ao comentar a Constituição americana, ${ }^{45}$ no que diz respeito à instituição do Poder Judiciário, fixou-lhe o dever de baluarte da Lei Fundamental, nos seguintes termos: " $a$ Constituição quis colocar os tribunais judiciários entre o povo e a legislatura, principalmente para conter esta última nos limites de suas atribuições. A Constituição é e deve ser considerada pelos Juizes como a lei fundamental; e como a interpretação das leis é a função especial dos tribunais judiciários, a eles pertence determinar o sentido da Constituição ... Mas não se segue daí que o Poder Judiciário seja superior ao Legislativo: segue-se, sim, que o povo é superior a ambos $e$ que, quando a vontade do corpo legislativo, declarada nos seus estatutos, está em oposição com a do povo, declarada na Constituição, é a esta última que os juizes devem obedecer: por outras palavras, que as suas decisões devem

43. O termo é grafado por Cappelletti, M. \& Garth, B., Acesso à Justiça. Trad. Northefleet, E.G., PA., S.A.Fabris, 1988.

44. Referimo-nos a Dinamarco, C.R., A instrumentalidade do processo, São Paulo, Revista dos Tribunais, 1987; e a Watanabe, K, Da cognição no processo civil, São Paulo, Revista dos Tribunais, 1987.

45. Trata-se de Alexander Hamilton, nos Federalist Papers, conjunto de textos que incluem a contribuição, também, de James Madison e John Jay. 
conformar-se antes com as leis fundamentais do que com aquelas que o não são". 46

Em atenção a tão-elevado dever, o nosso segundo jurista, o precursor Justice Marshall estabeleceu, em decisão sempre citada, ${ }^{47}$ o controle de constitucionalidade: "parece apenas necessário reconhecer certos princípios ... que o povo tem um Direito originário de estabelecer, para seu futuro governo, tais princípios que, em sua opinião, provavelmente melhor conduzirão à sua felicidade, é a base sobre a qual toda a estrutura americana tem sido erigida. $O$ exercício deste Direito original demanda um enorme esforço ... Os princípios, portanto, assim estabelecidos, são considerados fundamentais ... Qual o propósito de serem os poderes limitados e aqueles limites consignados por escrito, se puderem, a qualquer tempo, ser ultrapassados por limites considerados como estritos? ... É da competência especial, bem como o dever do Poder Judiciário dizer o que é o Direito. Aqueles que aplicam a regra a casos particulares devem, necessariamente, expor e interpretar aquela regra. Se duas leis entram em conflito, os tribunais devem decidir sobre a aplicação de cada uma ... A Corte deve determinar qual destas regras em conflito governa o caso; isto é da própria essência do dever judiciário".

Ora, aqui, somente se está a levar tão-nobre função às suas conseqüências naturais, devolvê-la ao seu berço original.

A legitimidade é dogma constitucional derivado do princípio democrático.

Destarte, comenta o Professor Titular do Departamento de Processo da Faculdade de Direito da Universidade de São Paulo: ${ }^{48}$ " a visão exterior do sistema processual torna particularmente perceptível a imperiosa necessidade do exercício da jurisdição segundo regras e princípios que correspondam a padrões compativeis com a cultura contemporânea. Os valores vigentes no espírito das nações, hoje cada vez mais propensos à universalização, exercem poderoso tropismo sobre o sistema, determinando sua convergência a certas idéias fundamentais, que são os princípios instalados nas Constituições e revelados pelo trabalho dos juízes e doutrinadores; o empenho dos processual-constitucionalistas no sentido da

46. Aqui se grifou.

47. Marbury v. Madison, de 1803.

48. Dinamarco, C.R., ob. cit. 

proposta de Defensoria-Geral da Justiça

aproximação sempre maior entre processo e Constituição concorre de modo eficaz para a tomada de consciência desses valores e da medida e sentido da influência que exercem sobre o sistema processual, uma vez que, por destinação institucional, as cartas políticas abrigam em primeiro plano a consagração dos valores fundamentais da nacionalidade. A compatibilidade do sistema processual com essa realidade axiológica é o primeiro e mais importante fator de sua legitimidade"

E prossegue: "enquanto se pensasse somente na observância dos ditames constitucionais como exigências positivadas em patamar hierarquicamente superior às leis estruturadoras do sistema processual, ter-se-ia uma acanhada $e$ frágil visão legalista do problema, própria do positivismo jurídico, restrita às dimensões do direito e carente de raízes profundas. $A$ compatibilidade constitucional do sistema, assim, é forte indicador de sua legitimidade, mas não é em si mesma fator de legitimação, tanto quanto legitimidade não se reduz a legalidade". sublinhando: "aliás, para a própria descoberta do significado substancial dos dispositivos a permanente referência ao complexo axiológico da sociedade, neles espelhado (nem é de hoje a busca da legitimidade do poder em sua base popular: populus imperium et potestatem conferat)"

De dois modos se busca concretizar, lembra-nos o professor doutor Kazuo Watanabe, tanto a efetivação da ordem constitucional quanto a efetividade da tutela do direito: ${ }^{49}$ "uma dessas perspectivas é a de direito material. Os processualistas dessa tendência procuram desenvolver o estudo do direito subjetivo, da pretensão de direito material e da ação de direito material, conduzindo à conclusão de que, no plano processual, a cada ação de direito material corresponde, de ordinário, 'ação' de direito processual e uma pretensão processual ... a pretensão estaria perfeitamente ajustada à peculiaridade e à exigência da pretensão material ... A outra perspectiva é a de direito processual. Procuram os processualistas dessa tendência...aprofundar os estudos dos vários institutos $e$ técnicas processuais e por esse método de pensamento buscar a melhor tutela dos direitos através do processo ... Ambas as perspectivas são igualmente relevantes. Devem mesmo constituir-se num método de pensamento unitário, de modo que se atinja, pelos esforços concêntricos partidos de ambos os pólos, o objetivo comum, que é o de tutela efetiva de todos os direitos. Se de um lado há exigências próprias

49. Ob. cit. 
do direito material por uma adequada tutela, há de outro as técnicas e soluções específicas do direito processual"

E arremata: "o ponto de confluência das duas correntes é alcançado pela pesquisa dos aspectos constitucionais do processo civil ... Ainda a considerar a dimensão 'constitucional' do direito e da justiça, que constitui uma das características das tendências evolutivas dos ordenamentos jurídicos contemporâneos": citando os professores Cappelletti e Garth: dimensão que se traduz "nella reicerca di taluni valori fondamentali che molti ordinamenti moderni hanno affermato com norme aventi forza di lex superior, vincolante anche per il legislatore (ordinario), spesso imponendone il rispetto medianti forme e meccanismi speciali giurisdizionali"

Enfim, nosso regime democrático consagra a soberania popular: a origem e a fonte do poder são e estão no povo. Seu exercício é deferido a representantes se e somente na condição de serem eleitos.

Sem tal qualificação constitucional, não-há representação.

Ou, o que é dizer o mesmo, a representação não é adequada sem legitimidade.

2. A questão, pois, do princípio democrático aplicada à representação dos interesses coletivos e difusos, consoante analisada até aqui, está a apontar os equívocos - seja da previsão constitucional, seja da doutrina em restringir sua análise à perspectiva meramente processual, o que vem a comprometer o próprio exercício de direitos públicos consagrados: malefício, pois, à democracia.

Como aqui se estabeleceu, o exercício da tutela dos interesses coletivos e difusos se apresenta como manifestação ou atributo societal e nunca estatal: da sociedade pelos instrumentos de estruturação e funcionalização do modo de ser social evidentemente em seus aspectos consensual e conflitual, ${ }^{50}$ com vistas à ocupação de novos espaços públicos ou recuperação de sua capacidade jurídicopolítica.

É evidente, pois, que um órgão do Estado, que desempenhe funções de sua defesa ou próprias deste ente, não pode desejar legitimamente desincumbir-se da tutela dos interesses societais, ${ }^{51}$ a não ser no seio de uma tradição que conforme

50. Em uma palavra, pluralisticamente garantido.

51. Vamos, a partir de agora, guardar esta categoria de síntese. 

proposta de Defensoria-Geral da Justiça

uma reivindicação - nitidamente corporativista (estatal, como a nossa), em que o Estado, dizendo tutelar, em verdade procura controlar.

A partir, pois, dessas premissas, passo a criticar o estatuto pretendido pelo Ministério Público.

\section{A. A Constituição}

O título IV da Constituição Federal refere a organização dos poderes.

$\mathrm{O}$ capítulo $I V$, sob a rubrica das funções essenciais à Justiça, estabelece os lineamentos do Estatuto do Ministério Público, em sua seção I, nos arts. 127 a 130 , inclusive.

Definido como instituição permanente voltada à defesa da ordem jurídica, do regime democrático e dos interesses sociais e individuais indisponíveis.

Tal instituição possui um chefe, denominado Procurador-Geral da República, no âmbito federal e Procurador-Geral, nos Estados e Distrito Federal.

A escolha do chefe se dá sempre dentre os integrantes da carreira, sendo sua nomeação um ato complexo: na esfera federal, por indicação do Presidente da República, após aprovação pelo Senado Federal; no estadual, por escolha do Governador de um dos nomes da lista tríplice, cujos Ministérios Públicos formarão.

A idéia de um chefe já contradiz o princípio da independência funcional.

Ocorre, contudo, que a ênfase dos princípios põe-se nas idéias, a rigor reduzíveis uma à outra, da unidade e da indivisibilidade.

Observe-se, ainda, que a iniciativa da lei que organiza, prevê as atribuições e estabelece o estatuto da instituição a sua lei orgânica-pertence a tal chefe.

Mesmo se admitirmos que, em alguns casos, o Procurador-Geral venha a solicitar contribuições dos demais membros da carreira à sua proposta, nada disto retirará o caráter corporativista estatal deste modo de conceber o Ministério Público, aliás corroborado pela forma prescrita de ingresso na carreira, em que, do concurso público, organizado pela própria instituição, a partir de seu chefe, só se assegura a participação de outra corporação: a Ordem dos Advogados do Brasil.

Se o órgão, na estipulação constitucional, somente exercesse funções próprias do Estado, ainda poderíamos admitir se bem que a concessão já se mostra demasiado larga a absoluta exclusão da participação, sequer o controle popular. 
Entretanto, houve por bem desejar o constituinte neste interessante amálgama de contribuições sociais díspares a configurar nossa Charta que o Ministério Público também desempenhasse a representação da sociedade aliás gravemente confundida com a de seus corpos intermediários. ${ }^{52}$

Esqueceu-se, porém, como já se fez observar, de legitimar a pretensa representação.

Função estatal é, notadamente, a de dar início à ação penal pública: quem possui o monopólio do emprego da violência é, na modernidade, o Estado, que não pode permitir que grupos sociais o substituam neste mister. Isto porque a atuação dos indivíduos, em matéria de estabelecimento da punição em face de qualquer ato de transgressão da ordem jurídica penal, em geral se mostra arbitrária e irresponsável perante as garantias aos direitos fundamentais, mormente em uma sociedade crescentemente massificada, cujas experiências têm-se tornado mediatizadas por meios de comunicação incontrolados. ${ }^{53}$

Em face, por hipótese, da inação do Ministério Público fato mais grave até do que sua atuação arbitrária ou discricionária que remédio terá a sociedade?

Corolário, prosseguindo, de tal atribuição é o exercício do controle externo da atividade policial, urgente perante nossa pobre realidade de trabalho da polícia civil e da irrestrita atuação da polícia militar.

Não se estaria no momento apropriado de criar o Juiz de instrução criminal; não seria este o bom espaço a ser ocupado pelos membros do Ministério Público?

Neste âmbito do exercício da atividade estatal, andou corretamente a Constituição, ao fornecer garantias aos promotores (vitaliciedade, inamovibilidade e irredutibilidade de vencimentos), bem como ao permitir-lhes expedir notificações e requisitar informações para instruir processos administrativos, ao proibir-lhes a representação judicial e a consultoria jurídica de entidades públicas, receber honorários, custas e percentagens processuais, exercer a advocacia, qualquer outra

52. A Constituição confunde, sem cerimônia, interesse social com público, e parecer ignorar, sobranceramente, o que sejam interesses coletivos e difusos... Tudo isto em nome de sua proteção?...

53. Do ponto de vista democrático. Observar-se-á, bem a propósito, que as concessões de uso das estações de televisão e de rádio perfazem-se no seio de outra concepção corporativista estatal (art. 223 e seu parágrafo primeiro, da Constituição Federal). 

proposta de Defensoria-Geral da Justiça

função pública e atividade político-partidária, participar de sociedade comercial, $e$ ao determinar-lhes a residência na comarca da respectiva lotação.

Não desejando, por ora, exaurir toda a gama de críticas e de sugestões ao aperfeiçoamento do texto constitucional, cumpre, a par da análise que abriu a presente contribuição, estabelecer de que modo se poderia veicular adequadamente a tutela dos interesses individuais indisponíveis, dos interesses coletivos e dos interesses difusos.

Antes de tudo, a defesa da ordem jurídica e do regime democrático a todos incumbe: é, pois, um dever a que se submete também o Ministério Público e nunca uma atribuição, muito menos exclusiva, de qualquer entidade. ${ }^{54}$

Dito isto, cumpre interpretar o que a Constituição entende por interesses sociais e individuais indisponíveis, evidentemente ligados à previsão do inquérito civil e da ação civil pública, para a proteção do patrimônio público e social, do meio ambiente e de outros interesses difusos e coletivos, à defesa judicial dos direitos e interesses das populações indígenas, à propositura da ação de inconstitucionalidade. ${ }^{55}$

A ação civil pública e ação de inconstitucionalidade devem ser entendidas como verdadeiros remédios constitucionais, como tais merecendo lugar no art. $5^{\circ}$, na forma como a seguir se esboça:

"São remédios constitucionais:

- A ação declaratória de inconstitucionalidade por ação ou omissão do Poder Público, cuja legitimidade é concedida :

1- incidentalmente, qualquer parte em processo judicial;

2-por via direta:

54. Note-se, aqui, uma vez mais, o desvirtuamento de conceitos, prescrevendo-se um dever (e, portanto, direito já proclamado no art. $5^{\circ}$ ) - de todos, sublinhe-se de zelar pelo efetivo respeito dos Poderes Públicos e dos serviços de relevância pública aos direitos assegurados na Constituição, promovendo as medidas necessárias a sua garantia, à guisa de função institucional. Cabe indagar o porquê deste obsessivo interesse de cautelar os indivíduos e a sociedade por um órgão estatal, a rigor ligado, pela chefia, ao Poder Executivo estadual e federal, à Casa de Representação dos estados, no Congresso Nacional e, aqui também na forma de recrutamento, aos próprios critérios e interesses da corporação.

55. Posta, ainda, ao lado da representação para intervenção União e dos Estados, como se se tratasse de questões do mesmo grau. 
*. o Presidente da República

*. a Mesa do Senado Federal

*. a Mesa da Câmara dos Deputados

*. a Mesa da Assembléia Legislativa

*. o Governador de Estado

*. o Procurador-Geral da República

*. o Defensor Geral da Justiça

*. o Conselho Federal da $O A B$

*. Partido Político com representação no Congresso Nacional

*. Confederação Sindical ou entidade de classe de âmbito nacional

*. Associação que vise à defesa de interesse coletivo ou difuso de representatividade nacional

- O mandato de injunção...cuja legitimidade é conferida à qualquer pessoa física ou jurídica prejudicada pela ausência de ...

1- A omissão, reconhecida por qualquer Juízo ou Tribunal, será suprida temporariamente por ele, nos limites do caso julgado e de sua competência, marcando-se prazo não-superior a trinta dias, sob pena de responsabilização, ao órgão que teria o dever de regular a determinação constitucional.

A ação civil pública, para a defesa de interesses difusos e coletivos e para a proteção do patrimônio público e social, cuja legitimidade é conferida à União, aos Estados, Municípios, autarquias, fundações $e$ associações constituídas há pelo menos um ano, nos termos da lei civil, que incluam entre suas finalidades institucionais a proteção aos interesses difusos ou coletivos que venham a defender, e, subsidiariamente, $\grave{a}$ Defensoria Geral da Justiça, quando, em face de ameaça a interesse coletivo ou difuso e ao patrimônio público ou social, constatar-se a inexistência de 
associação ou fundação ou a omissão de qualquer das entidades legitimadas neste dispositivo.

1- A Defensoria Geral da Justiça, em qualquer dos casos, prestará assessoria a associações ou fundações que venham a defender interesses coletivos ou difusos.

- ação popular

- mandado de segurança coletivo

- mandado de segurança individual

- habeas-corpus

- habeas-data"

Observa-se, portanto, a criação de um novo órgão - a Defensoria Geral da Justiça, a substituir a tímida previsão atual da Defensoria Pública (art. 134 e parágrafo único).

Tal órgão subtrai ao Ministério Público as funções de representação de interesses societais, assumindo-as, contudo, de um modo muito distante de uma concepção corporativista estatal.

Titulares dos interesses coletivos e difusos são os grupos da própria sociedade.

Desfaz-se a confusão entre interesse público que respeita a toda a sociedade, sempre fragmentada e pluralisticamente organizada - e o interesse social correspondente a cada uma das múltiplas maneiras de organização das classes, grupos e categorias sociais.

Fortalece-se a sociedade.

A seguir, garantida a sua participação e controle, são fortalecidos a Defensoria Geral da Justiça instrumento assessor dos interesses societais - e o Ministério Público instrumento que veicula interesses estatais, consoante aqui se anotou.

Destarte, dentre as funções essenciais à Justiça, temos:

"- Ministério Público: instituição permanente cujas funções são estatais, quais sejam, promoção privativa da Ação penal pública, o controle da atividade policial, exercendo a tarefa do juízo de instrução prévia criminal, podendo expedir notificações ... requisitar diligências investigatórias ... (v. incisos respectivos do art. 129), exclusivamente, não se permitindo a extensão das funções, bem como vedada a representação judicial e consultoria jurídica das entidades 
públicas, bem como afastamento de membro para exercício de qualquer função legislativa ou executiva.

Defensoria Geral da Justiça: instituição permanente a qual incumbe as funções de promover, na forma prevista no art. $5^{\circ}$ (esboço supra), subsidiariamente, inquérito civil e ação civil pública, para a proteção do patrimônio público e social e dos interesses coletivos e difusos, a defesa judicial dos direitos e interesses das populações indígenas, a assessoria jurídica às associações e fundações referidas no mesmo dispositivo, a orientação jurídica e a defesa dos necessitados, sendo vedado o afastamento de seus membros para o exercício de qualquer função legislativa ou executiva.

Organização em carreira e garantias a tais instituições".

A isto se acresce, ainda como forma de participação e controle sociais:

"- A função de Defensor Geral de Justiça é eletiva direta, devendo recair sobre cidadãos de ilibada reputação e notável saber jurídico; é temporária (três anos) e não se admite a recondução sucessiva em nenhum caso; o Conselho da Defensoria será eleito por seus membros sem distinção de nível;

A função de Procurador Geral da República e ao Conselho do Ministério Público se aplicam as mesmas normas".

Tudo aconselha, enfim, que se estabeleça para o Presidente da Ordem dos Advogados do Brasil e para o seu Conselho Federal o mesmo modo de escolha, bem como que se unifiquem os concursos de ingresso no quadro da $O A B$ e nas carreiras jurídicas, sem qualquer exceção, criando-se critérios de participação $e$ controle popular sobre a formação dos profissionais jurídicos.

Feitas tais observações, passemos à análise dos Estatutos Federal e Estadual que se deram ou se pretendem presentear os dignos Promotores de Justiça.

3.B. A Lei Orgânica do Ministério Público Federal

A análise, neste capítulo, será levada a cabo dentro dos limites da previsão constitucional vigente.

Trata-se, aqui, da Lei Federal n. 8.625 de 12.02.93 (publicada no Diário Oficial da União de 15.02.93), que institui a Lei Orgânica Nacional do Ministério Público e dispõe sobre normas gerais para a organização do Ministério Público dos Estados. 
3.B.1. A primeira crítica que se pode estabelecer à lei orgânica reside na completa ausência de distinção entre as funções estatal e societal na estipulação das atribuições dos órgãos do Ministério Público. Tudo se passa como se promover a ação civil pública significassem a mesma coisa.

Ora, não é apenas ao nível da diferenciação das funções em estatais e societais que se está a exigir um estatuto diverso (até, como acima se observou, com a previsão de órgãos distintos). Mesmo na visão tradicional, há que se observar a diferente natureza dos processos gerados pelo exercício daquelas funções.

No processo penal, quando presentes e fortemente asseguradas as garantias constitucionais aos indivíduos, pode-se pensar no Estado, pelo seu órgão encarregado de ativar a persecução, requisitando documentos e diligências de outros órgãos públicos e compelindo particulares à participação. ${ }^{56}$ Trata-se, aqui, é bom reprisar o argumento, de um interesse público que se confunde com o interesse estatal: garantir o monopólio do emprego legítimo da violência pelo Estado um Estado, lembre-se, fortemente circunscrito ao estatuto de proteção aos cidadãos. ${ }^{57}$

No processo civil, contudo, mesmo que essencialmente renovado pelo advento dos interesses coletivos e difusos, a função permanece distinta daquela do penal, bem como o modo de sua concretização, mormente porque o interesse público, aqui, não se confunde e mesmo repele qualquer assimilação ao interesse estatal. Em face desses interesses, bem como de suas garantias, não se pode permitir que o órgão estatal atue sob a mesma óptica, por assim dizer, inquisitória. ${ }^{58}$

Isto porque, fundamentalmente, a adequação dos interesses coletivos e difusos ao interesse social comum se estabelece no seio de um processo, de uma construção histórica, controlados desde a origem a legitimidade ${ }^{59}$ - pelo titular do poder.

56. Sempre sob o controle do Poder Judiciário.

57. Aos direitos e garantias fundamentais (art. $5^{\circ}$ e passim da Constituição Federal), aos fundamentos, objetivos e princípios da República Federativa do Brasil (arts. $1^{\circ}, 2^{\circ}, 3^{\circ}$ e $4^{\circ}$ ), bem como àqueles da legalidade, impessoalidade, moralidade e publicidade (art. 37).

58. Na expressão sempre feliz da professora doutora Ada Pellegrini Grinover: "mas a verdade é que a solução constitucional para a problemática das ações ideológicas há de ser buscada numa óptica social e coletiva, capaz de amoldar as garantias clássicas à configuração típica dos conflitos de massa: numa dimensão que será necessariamente diversa, mas que não-significará o seu abandono" (Novas tendências do direito processual, Rio de Janeiro, Forense Universitária, 1990).

59. Ou, se se desejar, a representação adequada. 
Diga-se isto até como crítica à visão doutrinária e do senso comum, para a qual tal adequação - extremamente complexa parece se mostrar um dado $a$ priori, portanto germinado de totalitarismo.

No processo relativo a tais interesses, conflitos coletivos se oferecem à apreciação do julgador e, somente após sua conclusão, poder-se-á afirmar qual deles mais se aproxima do social comum. Somente uma visão autoritária do direito permitiria que se considerasse essa aproximação revelada desde o início, seja pela lei, seja pela simples razão da propositura de uma ação por um órgão do Estado.

O julgador deve assumir posição mais atuante, no sentido de equilibrar as partes no processo, possibilitando-lhes concreta oportunidade de realizar todas as demonstrações possíveis de seus argumentos, atendendo sempre à fiscalização dos interessados, por meio dos princípios da defesa e do contraditório. Cabe-lhe compelir as partes à colaboração, à participação real, determinando provas, proporcionando meios à sua realização. Permitindo o controle, contudo.

Id est, não se pode admitir, sem as garantias do processo, que uma parte venha, sob a ameaça de uma sanção que não é processual, mas atributo de um órgão estatal a obrigar a outra a fazer prova em seu favor; que uma parte compareça diante da outra em franca posição de inferioridade. ${ }^{60}$ Isto quando o processo já impõe uma sanção clara ao que se omite em seu dever de demonstrar: a presunção ou mesmo a consideração da prova em seu desfavor.

Os estatutos devem ser diversos, mesmo que, lamentavelmente, como hoje ocorre, ao mesmo órgão se cometam funções de naturezas tão-diversas.

3.B.2. Há, em segundo lugar, uma tendência a organizar o Ministério Público com caráter prevalentemente monárquico: seja porque toda a instituição se unifica na figura de um chefe (assim insistentemente nomeado), cujas atribuições são elásticas ao extremo - se não deixadas em aberto; seja porque a lei parece ter estabelecido um princípio de relativa responsabilidade, se pensarmos no órgão inserido nos parâmetros da unidade e da indivisibilidade, uma corporação estatal, portanto - como titular do monopólio do desencadeamento da ação penal pública.

No âmbito dos órgãos de administração (capítulo III da lei), cabe, desde logo, indagar a ausência de limites ou a fórmula vaga de integração de membros do Ministério Público a organismos estatais afetos a sua área de atuação

60. Refiro-me à requisição e à intimação feitas pelo órgão do Ministério Público, sob pena de desobediência a gerar processo criminal. 
(art. 10, inciso VIII, alínea c), por designação do Procurador-Geral, ou, o que se mostra mais grave, a perpetuação do equívoco constitucional de permitir, no art. 29, $\S 3^{\circ}$ : do Ato de disposições constitucionais transitórias, ${ }^{61}$ a opção pelo regime anterior, como se se tratasse de interesse particular do agente público e não da sociedade o afastamento para desempenho de outra função na Administração direta ou indireta (art. 75 da lei orgânica).

Quanto ao Procurador-Geral de Justiça, o art. 29 acaba por admitir a fixação de suas atribuições como órgão de execução a qualquer lei, deixando margem à acumulação de funções, senão a sua concentração.

Cabe, enfim a indagação: quem controla o Ministério Público?

No caso de infração penal em abstrato cometida por qualquer dos membros da instituição, tanto a apuração quanto o oferecimento de denúncia permanecem no âmbito de atribuições do chefe da instituição (art. 29, inciso V, art. 40, inciso IV e parágrafo único do art. 41).

Não seria o caso de incumbir a órgão diverso a investigação e o dar início ao processo em tais casos?

Finalmente, quando da decisão de arquivamento ou na demora injustificada de dar andamento à apuração de sua responsabilidade, qual o remédio cometido aos cidadãos para a salvaguarda de seus direitos, se tudo permanece fechado no âmbito de atribuições do próprio órgão (parágrafo único do art. $3^{\circ} \mathrm{e}$ art. 29, inciso VII).

Mostram-se, pois, tímidas a concepção e a previsão de controle externo postas no $\S 2^{\circ}$ do art. $4^{\circ}$ citado.

3.B.3. Como se concretiza o controle externo da atividade policial?

$\mathrm{O}$ art. 25 não explicita.

3.B.4. O art. 26, quando estipula a possibilidade de o Ministério Público requisitar informações, exames periciais e documentos dos Poderes Legislativo e Judiciário é forçosamente inconstitucional.

Muito se poderia apostilar ao princípio consagrado no art. $2^{\circ}$ da Constituição Federal.

61. Parece ter-se tomado uma praxe a negação, à guisa de disposição transitória, dos princípios postos no texto constitucional. 
Basta, contudo, a reprodução do magistério do professor doutor Geraldo Ataliba, que afirma não consentir à Constituição que "o órgão ou agente do Poder Judiciário cuja precípua função constitucional é aplicar a lei com eficácia constrangedora, contra todos os órgãos e agentes públicos possa ser coagido, vendo ser-lhe aplicada a lei por órgão que não seja o órgão judicial que sobre ele tem a 'jurisdição natural'" 62

É o que está, de forma articulada, consagrado na conclusão do exaustivo estudo do professor titular das consagradas Faculdades de Direito da Universidade de São Paulo e da Pontifícia Universidade Católica de São Paulo: "a Constituição consagra um estado de direito ... Este caracteriza-se pela submissão do próprio Estado (e todos seus órgãos, inclusive os culminantes) à jurisdição ... Esta supõe imparcialidade (objetiva e subjetiva), que requer que os que a ela se submetem sejam parificados ... No momento de integrar a ordem jurídica, dizem-se soberanos (nos termos da Constituição) Legislativo e Executivo ... No momento de reintegrar-se a ordem jurídica (função jurisdicional), soberano é o Judiciário ... Para que isso possa ser realidade, o Judiciário não pode... ser sujeito a injunção, ordem, condicionamento ou coação de ninguém. Se isso fosse admitido, desmoronaria o sistema tão-engenhosamente armado (com base em sólida e provecta tradição), após penoso processo histórico e sociológico pela Constituição de 1988".

Não é, também, admissível que sejam dirigidas ordens por quem se faz parte em processo, ao Poder Legislativo, que perderia seu caráter de independência, bem como as prerrogativas que o sistema constitucional democrático lhe defere.

No exercício de suas funções, não se admitem "injunções ou requisições, irresistíveis (porque sancionadas como crimes)" aos Poderes Legislativo e Judiciário, que somente receberão, inclusive do Ministério Público, petições e solicitações, "jamais ordens coativas concretas"

São as considerações que, aqui, foram pinçadas, a fim de possibilitarem uma primeira análise da importante lei, recentemente promulgada.

3.C. A proposta da Lei Orgânica Estadual

A lei orgânica nacional possui oitenta e quatro artigos. 

proposta de Defensoria-Geral da Justiça

O Anteprojeto de Lei Complementar pretendido pela Egrégia Procuradoria-Geral de Justiça possui duzentos e noventa e seis artigos, incluindo-se as disposições transitórias.

Quanto ao caráter monárquico, o texto não faz senão exacerbá-lo, ao pretender descer a minúcias, inclusive no que diz respeito a regras do processo de escolha da lista tríplice para a nomeação do Procurador-Geral.

$\mathrm{O}$ caráter corporativista estatal ainda mais se acentua em face das normas atinentes ao Procurador-Geral da Justiça, seja ao impedir o controle dos Poderes a propósito de sua destituição, seja inclusive, ao tentar estabelecer exaustivamente tal procedimento.

A partir da concentração de atribuições em mãos do chefe do Ministério Público, o que se busca é a estruturação do órgão, posto pela Constituição Federal como função essencial à Justiça, como entidade, malgrado ligada ao Poder Executivo pela escolha de seu chefe, imune a um sistema mínimo de controle constitucional.

Se garantir a autonomia orçamentária se mostra fundamental à concretização do mandamento constitucional, inadequada será a interpretação que permita à lei complementar estabelecer detalhes no que diz respeito à remuneração de seus membros, notadamente quando estabelece gratificação por exercício de funções da Administração superior da carreira.

$\mathrm{O}$ anteprojeto parece, ainda, considerar permanente a possibilidade do afastamento para o exercer ou concorrer a funções legislativas e executivas, bem como admite o exercício de atividades político-partidárias aos membros da instituição.

O apetite pela regulação da instituição estadual leva a paradoxos, notadamente anunciando, de forma ilusória, dispositivos que garantem independência, ao mesmo tempo em que o órgão ou seus interesses se apresentam subordinados aos do exercício de funções legislativas e executivas, quando se o considera como afastamento temporário.

A enunciação constitucional de representação da sociedade fica comprometida pelo que se pode considerar como manifestação dos autores do anteprojeto em direção aos ritos, gestos e imagens mais próprios a uma configuração arcaica de um poder monárquico absolutamente afastado $e$ pairando irresponsavelmente sobre uma população bestializada. 
É como se deve tomar a pretensa prerrogativa de "tomar assento contígüo à direita e no mesmo plano dos Juízes", bem como a previsão de um processo disciplinar que permita a punição em face da "verdade sabida".

$\mathrm{O}$ afastamento da população até por símbolos, bem como a tentativa de, como parte, portanto sujeita ao princípio da representação, superar os demais representantes de partes, cujas funções também são garantidas constitucionalmente, ainda mais sublinham os perigos da ilegitimidade apontados inicialmente.

Resta aguardar a apresentação à população em geral do estatuto desejado pelo Ministério Público Estadual.

Somente a discussão pela sociedade, efetuada de forma ampla e transparente, em que os membros do Ministério Público justifiquem suas pretensões e se submetam ao controle democrático, poderá apontar a distinção, tão-necessária em nosso país, entre uma atribuição efetiva de controle e outra que pretenda a contigüidade com o poder, sinônimo da violência, como expressava Walter Benjamin.

\section{Conclusão}

Acredito que, da forma como está previsto o Estatuto do Ministério Público, dificilmente será possível prever quais os interesses que, efetivamente, está apto a defender ou representará, em concreto, no seio de uma sociedade absolutamente fragmentária, como a brasileira.

Tão-genérica estipulação constitucional e ordinária somente reitera o caráter de ilusão que o direito, entre outras funções, possui em nosso país. Pensa-se sempre em interesses assegurados somente em face de previsões abstratas.

Afirmo, contudo, que, diante das características de formação dos profissionais jurídicos, em geral, a atuação do Ministério Público poderá acabar por se reduzir a, pendularmente, duas facetas de representação de nossa pobre cultura contemporânea: ideológica ou de massa. ${ }^{63}$

63. Adorno, Th. ("Os padrões da cultura de massa" in Cardoso, F.H. \& Martins, C.E. (org.) Política e Sociedade, São Paulo, Cia. Editora Nacional, s.d., v. 2): "A crescente força da cultura de massa moderna é acentuada ainda mais pelas mudanças na estrutura social do público. A velha elite culta não existe mais; a moderna intelligentsia corresponde apenas parcialmente a ela. Ao mesmo tempo, uma enorme camada da população, que antes não estava habituada à arte, transformou-se em consumidora de cultura ... Isso se reflete na cultura popular ... A 'ontologia' da classe média foi preservada de forma quase fossilizada, embora se choque com a mentalidade atual das classes médias. Ao se impor sobre pessoas com cujas condições de vida e modo de pensar não está mais de acordo, essa 'ontologia' da classe média assume um caráter cada vez mais autoritário e ao mesmo tempo fictício ... A maldição da cultura de massa moderna parece ser sua aderência à quase imutável 

proposta de Defensoria-Geral da Justiça

Cumpre saber se à nossa civilização poder-se-á repetir a exclamação de Virgilio: Incipit vita nova; ou a lamentação de Jeremias: Quomod sedet sola civitas plena populo! Facta est quasi vidua domina gentium...

Salto, março de 1993. 